\title{
Russell body gastritis: case report
}

\author{
Gastrite com corpúsculos de Russell: relato de caso
}

Eduardo Cambruzzi ${ }^{1}$; Karla Lais Pêgas²; Fernanda de Fátima Laus ${ }^{3}$

\section{key words} Gastritis

Plasma Cells

Pathology

Helicobacter pylori

Russell Body

\section{abstract}

Russell body gastritis (RBG), which can be associated with Helicobacter pylori (HP) infection, is a recently acknowledged lesion characterized by the presence of eosinophilic intracytoplasmic inclusions in plasmacytes. Herein the authors discuss the morphological aspects of a case of RBG in a male patient with clinical complaint of epigastric pain. Upper endoscopy revealed areas of erythema/edema in the antrum. As far as microscopy is concerned, a mononuclear inflammatory infiltrate was identified on the lamina propria, with plasma cells containing Schiff acid periodic (PAS) positive eosinophilic intracytoplasmic globules, which showed positive immunostaining for CD79a, CD138, and kappa/lambda light chains. HP was identified by Giemsa stains. resumo

A gastrite com corpúsculos de Russell (RBG), que pode estar associada à infecção por Helicobacter pylori (HP), é uma lesão recentemente reconhecida que se caracteriza pela presença de inclusões eosinofilicas intracitoplasmáticas em plasmócitos. Neste relato, os autores discutem os aspectos morfológicos de um caso de RBG em um paciente masculino com queixa clínica de dor epigástrica. A endoscopia revelou áreas de eritema/edema no antro. À microscopia, um infiltrado inflamatório mononuclear foi identificado na lâmina própria, com plasmócitos exibindo glóbulos eosinofílicos intracitoplasmáticos ácido periódico de Schiff (PAS) positivos, que apresentaram imunoexpressão positiva para CD79a,CD138 e cadeias leves kappa/lambda. HP foi identificado na coloração de Giemsa.
Primeira submissão em 16/04/11 Última submissão em 29/10/11

Aceito para publicação em 05/12/11

Publicado em 20/02/12 


\section{Introduction}

Chronic gastritis is characterized by some histologic features that include increased numbers of mononuclear inflammatory cells, progressive destruction and atrophy of glands, and intestinal metaplasia. Signs of active disease include epithelial cell regeneration, with variable erosion, and neutrophilic reaction in lamina propria and epithelial layer. The lesion is usually confined to the mucosal layer, and eventually can be associated with hyperplasia of surface cells, and the appearance of lymphoid nodules $(6,10,18)$. Three distinct forms of chronic gastritis can be delineated: diffuse antral, fundic, and multifocal, being Helicobacter pylori (HP) infection one of the most common causes of this process ${ }^{(6,10)}$.

$\mathrm{HP}$ is a curved spirals, microaerophilic Gram-negative bacterium, about 3 micrometers length and with a diameter of about 0.5 micrometers, that is easily identified in the superficial mucous layer on hematoxylin-eosin (HE) and Giemsa stains, and produce oxidase, catalase, and urease. Following HP infection the antral superficial mucosa may become inflamed producing acute gastritis and then chronic active gastritis. With time, the mucosa shows a dense infiltrate of chronic inflammatory cells, usually rich in plasma cells, that extends for variable distances into the glandular compartment. Occasionally, chronic gastritis can be associated with the development of Russell bodies, which are eosinophilic, large, homogenous immunoglobulin-containing cytoplasmic inclusions, usually found in plasma_cells undergoing excessive synthesis of immunoglobulin $(2,4,6,10,14,17)$.

The authors report a new case of the so called Russell body gastritis, and review the histopathological findings of this uncommon lesion.

\section{Case report}

A 73-year-old male patient returned to the service clinic after the diagnosis of a well differentiated squamous cell carcinoma of the larynx, being treated with total laryngectomy and neoadjuvant chemotherapy. At present consultation the patient complained of epigastric pain. The upper gastrointestinal endoscopy showed areas of a moderate erythema, edema and small erosions in the gastric antrum. Multiple gastric biopsies from the body and antrum were taken. On histopathologic evaluation, a moderate mononuclear inflammatory infiltrate in the lamina propria associated with hyperplasia foveolar and predominance of plasma cells was found in the antrum (Figure 1). In a fragment, several plasma cells showed numerous Schiff acid periodic (PAS) positive intracytoplasmic eosinophilic round structures (Figure 2), that displaced the nuclei to the periphery. These globules showed positive immunostaining for CD79a, CD138, and kappa and lambda light chains of immunoglobulins, and negative immunostaining for pan-cytokeratins (AE1/AE3), being compatible with Russell bodies. Congo red stain was also negative. No cellular atypia, lymphoepithelial lesions, or atypical mitoses were identified. Using the technique of Giemsa, it was identified the presence of HP. The diagnosis of Russell body gastritis was then performed.

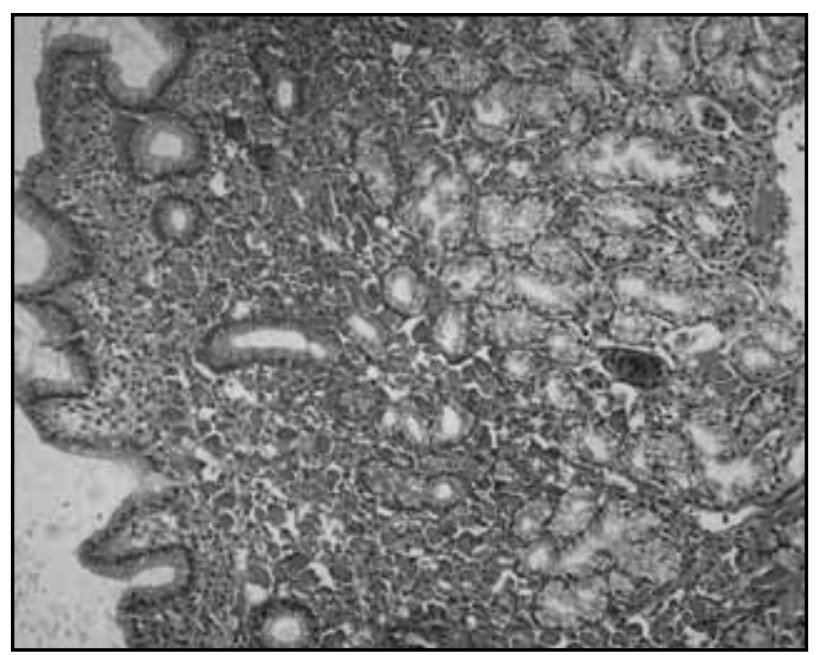

Figure 1 - Gastric biopsy showing a moderate mononuclear inflammatory infiltrate in the lamina propria with predominance of plasma cells, hematoxylin-eosin, 100x

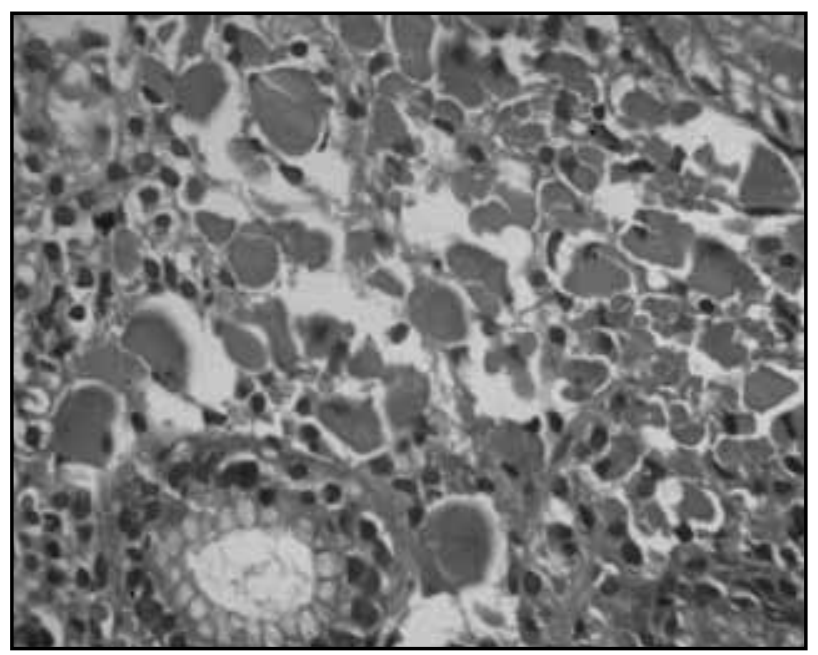

Figure 2 - Gastric biopsy showing several plasma cells with numerous intracytoplasmic eosinophilic round structures compatible with Russell body, hematoxylin- eosin, 400x 


\section{Discussion}

In 1890, Russell described the presence of spherical hyaline corpuscles in cells located in the vicinity of certain malignant tumors that he thought were fungi representing the etiological agent of cancer ${ }^{(15)}$. It is now accepted that the cells containing these corpuscles are plasma cells present in chronic inflammatory reactions in which there is prolonged antigenic stimulation. The hyaline substance corresponds in particular to the accumulation of immunoglobulin $\mathrm{G}(\mathrm{lgG})$ in the cytoplasm of plasma cells within the endoplasmic reticulum cisternae, which take a globular or morular aspect. The reason that these immunoglobulins are not eliminated and crystallize in the cytoplasm remains to be established. It looks that the synthesis of a mutated $\lg G$, which is neither secreted nor degraded, is sufficient to induce Russell body formation. Ultrastructurally, dilated endoplasmic reticulum cisternae containing condensed aberrant proteins can be found in plasma cells and secretory cells of different origin, suggesting condensation of transport-incompetent protein (a secretion disturbance) in the endoplasmic reticulum as a possible way for this morphological feature. In general, plasma cells filled with Russell bodies, also known as Mott cells, have been associated to immunoproliferative disorders

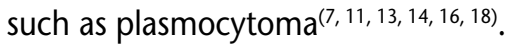

Plasma cells exhibiting Russell body can be seen in the mucosal surface of the gastrointestinal tract, including the cases of chronic gastritis related to HP infection. This agent causes damage to both superficial and crypt cells by mechanisms mediated by inflammatory reaction and apoptosis. HP stimulates cytokine production, such as interleukin-1, interleukin-6, inteleukin-8, and tumor necrosis factor, by epithelial cells that recruit and activate immune and inflammatory cells, such as plasma cells in the underlying lamina propria, causing chronic gastritis, with occasional formation of lymphoid aggregates. The presence of diffuse plasma cell infiltration with Russell body formation is suggestive of an interaction between HP infection and gastric immune system, since this agent determines a chronic inflammatory process in the gastric mucosa. The over-stimulation of plasma cells by mucosal pathogens could lead to the accumulation of excess amounts of $\lg G$

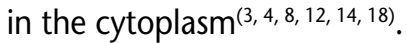

The clinical significance of Russell body gastritis is unclear. Endoscopic features were usually non-specific and included as well as swelling or scarring of the gastric mucosa. Occasionally, a plaque-like lesion can be found. The differential diagnosis of Russell bodies in the gastric mucosa includes plasmacytoma, lymphoplasmacytic lymphoma, and signet-ring cell carcinoma. The demonstration of lightchain restriction by immunohistochemestry technique enables the distinction between a reactive and a neoplastic plasma cell infiltrate. Signet-ring cell carcinoma show an infiltrative growth pattern, nuclear atypia, cells with clear and vacuolated cytoplasma, mitotic activity, and a positive immunoexpression for cytokeratins. Plasma cells associated with Russell body demonstrate homogeneous eosinophilic round inclusions that stain intensely in the PAS method, and are immunopositive for the antibodies CD79a, CD138, and kappa and lambda imunoglobulin light chain ${ }^{(1,2,4,5,8,9,14,16)}$. The authors suggest the use of the term gastritis with Russell bodies, since the presence of these corpuscles represents a cell alteration and not a cause of the disease.

Herein, the authors report a new case of gastritis with Russell body related to HP infection. The clinical and histopathological findings in the present case were very similar to that found in the previous reports, favoring the hypothesis that HP infection plays an active role in pathogenesis of this uncommon condition.

\section{References}

1. DE PETRIS, G. et al. Pseudoneoplasms of the gastrointestinal tract. Arch Pathol Lab Med, v. 134, p. 378-92, 2010.

2. DEL GOBBO, A. et al. Helicobacter pylori-negative Russell body gastritis: case report. World J Gastroenterol, v. 17, p. 1234-6, 2011.

3. DRUT, R. et al. Russell body gastritis in an HIV-patient. Int J Surg Pathol, v. 14, p. 141, 2006.

4. ENSARI, A. et al. An unusual presentation of Helicobacter pylori infection: so-called "Russell body gastritis". Virchows Archiv, v. 446, p. 463-6, 2005.
5. ERBERSDOBLER, A. et al. Russell body gastritis. An unusual, tumor-like lesion of the gastric mucosa. Arch Pathol Lab Med, v. 128, p. 915-7, 2004.

6. GENTA, R. M. Helicobacter pylori, inflammation, mucosal damage and apoptosis: pathogenesis and definition of gastric atrophy. Gastroenterol, v. 113, p. S51, 1997.

7. GRAY, A. et al. Ultrastructure of plasma cells containing Russell bodies in human stomach and thyroid. J Clin Pathol, v. 23, p. 608-12, 1970. 
8. HABIB, C. et al. Russel body gastritis. Am J Hematol, v. 85, p. 951-2, 2010.

9. JOHANSEN, A. et al. The diagnostic significance of Russell bodies in endoscopic gastric biopsies. Acta Pathol Microbiol Scand, v. 85, p. 245-50, 1977.

10. KOKOSKA, E. R. et al. Helicobacter pylori and the gastroduodenal mucosa. Surgery, v. 130, p. 13-6, 2001.

11. KOPITO, R. R. et al. Aggresomes and Russell bodies. Symptoms of cellular indigestion? EMBO Reports, v. 11, p. 225-31, 2000.

12. LICCI, S. et al. Russell body gastritis associated with Helicobacter pylori in an HIV-positive patient: case report and review of the literature. Zeitschrift für Gastroenterologie, v. 47, p. 357-60, 2009.

13. PAIK, S. et al. Russell body gastritis associated with Helicobacter pylori infection: a case report. J Clin Pathol, v. 59, p. 1316-9, 2006.
14. PIZZOLITTO, S. et al. Russell body gastritis: expanding the spectrum of Helicobacter pylori - related disease? Pathology Research and Practice, v. 203, p. 457-60, 2007.

15. RUSSELL, W. Address on a characteristic organism of cancer. BMJ, v. 2, p. 1356-60, 1890.

16. SHINOZAKI, A. et al. Prominent Mott cell proliferation in Epstein-Barr virus-associated gastric carcinoma. Hum Pathol, v. 41, p. 134-8, 2010.

17. TAZAWA, K. et al. Localized accumulation of Russell body-containing plasma cells in gastric mucosa with Helicobacter pylori infection: "Russell body gastritis". Pathol Int, v. 48, p. 242-4, 1998.

18. WOLKERSDÖRFER, G. W. et al. Monoclonal Gammopathy of undetermined significance and Russell body formation in Helicobacter pylori gastritis. Helicobacter, v. 11, p. 506-10, 2006. 